\title{
PENERAPAN SISTEM PAKAR DIAGNOSA PENYAKIT TERNAK DENGAN MENGGUNAKAN METODE FORWARD CHAINING (STUDI KASUS : DINAS PETERNAKAN KABUPATEN DHARMASRAYA)
}

\author{
Epri Yuldi 1), Helly Andri 2) \\ ${ }^{1}$ Fakultas Ilmu Komputer, Universitas Dharmas Indonesia, Koto Baru \\ ${ }^{2}$ Fakultas Ilmu Komputer, Universitas Dharmas Indonesia, Sungai Rumbai \\ email: epri.yuldi14@gmail.com
}

\begin{abstract}
Abstrak
Kabupaten Dharmasraya merupakan daerah dengan budi daya ternak cukup menjanjikan. Banyak sekali hewan yang dapat dibudidayakan dengan cara berternak. Pemerintah Dharmasraya sangat mendudukung masyarakat untuk beternak. Namun permaslahan yang terjadi di lapangan, peternak seringkali mengalami kegagalan dalam beternak seperti terjangkit penyakit bahkan sampai pada kematian hewan ternak. Hal ini dikarenakan peternak tidak mengetahui penyakit ternak dan kurangnya sumber daya manusia yang ahli dalam bidang tersebut. Oleh karena itu, untuk menangani masalah ini dibuatlah sebuah aplikasi sistem yang dapat mendiagnosis penyakit ternak. Aplikasi perlu adanya sebuah sistem yang dapat mendiagnosa penyakit ternak. Sistem ini dibangun menggunakan model sekuensial linier yaitu analisis, desain, penjabaran dan penalaran. Pembuatan aplikasi sistem ini menggunakan metode forward chaining.
\end{abstract}

Kata Kunci : Sistem, Pakar, Komputerisasi, Ternak, Forward Chaining

\section{PENDAHULUAN}

Hewan ternak merupakan salah satu bentuk investasi manusia untuk mendapatkan penghasilan. Hewan ternak merupakan salah satu media untuk investasi yang baik karena hewan ternak dapat dikembangbiakkan dan hasil nya dapat dijual atau dikembangkan lagi untuk kemudian dijual dengan harga yang sesuai dengan modal untuk merawatnya sampai pantas untuk di jual. Perawatan yang diberikan kepada hewan ternak tidak dapat asal-asalan saja.Karena hewan ternak juga makhluk hidup, untuk itu diperlukan teknik yang tepat untuk merawat serta memelihara hewan ternak.

Salah satu hal yang sering mengganggu peternak hewan adalah tentang penyakit hewan ternak. Penyakit yang terdapat pada hewan ternak berbagai macam bentuk nya dan dapat menimbulkan kerugian yang sangat besar artinya bagi perternak bukan saja dapat menurunkan harga dari hewan ternak tersebut tetapi juga akan menimbulkan kerugian besar bagi peternak yaitu kematian dari hewan tersebut.

Hewan ternak merupakan salah satu bentuk investasi manusia untuk mendapatkan penghasilan. Hewan ternak merupakan salah satu media untuk investasi yang baik karena hewan ternak dapat dikembangbiakkan dan hasil nya dapat dijual atau dikembangkan lagi untuk kemudian dijual dengan harga yang sesuai dengan modal untuk merawatnya sampai pantas untuk di jual. Perawatan yang diberikan kepada hewan ternak tidak dapat asal-asalan saja.Karena hewan ternak juga makhluk hidup, untuk itu diperlukan teknik yang tepat untuk merawat serta memelihara hewan ternak.

\section{METODE PENELITIAN}

Dalam melakukan penelitian ini penulis menggunakan metode Waterfall dalam melakukan perancangan sistem dan metode Inferensi Forward Chaining dalam melakukan pemecahan masalah yang ada.

\section{Model Waterfall (Air Terjun)}

Nama model ini sebenarnya adalah "Linear Sequential Model". Model ini sering disebut dengan "classic life cycle" atau model waterfall. Model ini adalah model yang muncul pertama kali yaitu sekitar tahun 1970 sehingga sering dianggap kuno, tetapi merupakan model yang paling banyak dipakai 
didalam Software Engineering (SE). Model ini melakukan pendekatan secara sistematis dan urut mulai dari level kebutuhan sistem lalu menuju ke tahap analisis, desain, coding, testing verification, dan maintenance. Disebut dengan waterfall karena tahap demi tahap yang dilalui harus menunggu selesainya tahap sebelumnya dan berjalan berurutan. Sebagai contoh tahap desain harus menunggu selesainya tahap sebelumnya yaitu tahap requirement.

Waterfall Model adalah sebuah metode pengembangan software yang bersifat sekuensial dan terdiri dari 5 tahap yang saling terkait dan mempengaruhi seperti terlihat pada gambar berikut :

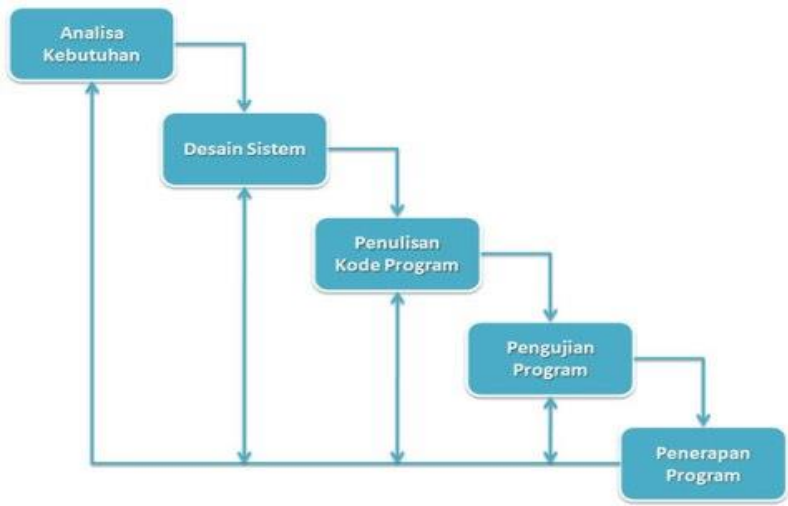

Sumber : http://www.budihermawan.net/?tag=waterfallmodel/

\section{Gambar Pemodelan Waterfall}

\section{Metode Inferensi}

Ada 2 metode inferensi yang penting dalam system pakar yaitu :

Runut jauh(forward chaining) dan runut balik(backward chaining). Namun pada pembahasan kali ini sesuai dengan metode yang penulis pakai maka penulis hanya akan menjelaskan tentang runut jauh (forward chaining).

\section{Konsep Sis tem Pakar}

Sistem pakar adalah sebuah perangkat lunak komputer yang memiliki basis pengetahuan untuk domain tertentu dan menggunakan penalaran inferensi menyerupai seorang pakar dalam memecahkan masalah.

\section{Ciri-Ciri Sistem Pakar}

Menurut Arhami [ARH04], dalam pembuatan sistem pakar harus diketahui ciri-ciri dan kategori masalah sistem pakar. Pada umumnya sistem pakar bersifat:

a. Memiliki informasi yang handal, baik dalam menampilkan langkah-langkah antara maupun dalam menjawab pertanyaan-pertanyaan tentang proses penyelesaian.

b. Mudah dimodifikasi, yaitu dengan menambah atau menghapus suatu kemampuan dari basis pengetahuannya.

c. Dapat digunakan dalam berbagai jenis komputer.

d. Memiliki kemampuan untuk beradaptasi.

\section{Komponen Sistem Pakar}

a. Basis Pengetahuan (Knowledge Base)

b. Mesin Inferensi (Inference Engine)

c. Basis Data

d. Antar Muka Pemakai

\section{Kelebihan Sistem Pakar}

Ada beberapa kelebihan yang dapat diperoleh dari pembuatan sistem pakar menurut Arhami [ARH04], yaitu:

a. Menjadikan pengetahuan dan nasihat lebih mudah didapat.

b. Meningkatkan output dan produktivitas.

c. Menyimpan kemampuan dan keahlian pakar.

d. Meningkatkan reabilitas.

e. Memberikan respons (jawaban) yang cepat.

f. Merupakan panduan yang cerdas.

g. Dapat bekerja dengan informasi yang kurang lengkap dan mengandung ketidakpastian.

h. Basis data cerdas, bahwa sistem pakar dapat digunakan untuk mengakses basis data dengan cara cerdas.

\section{HASIL DAN PEMBAHASAN}

Untuk memperoleh hasil yang efektif tentang penelitian sistem pakar dengan menggunakan metode forward chaingng yang akan diterapkan, maka peneliti merancang kerangka kerja. Adapun tahapan kerangka kerja sebagai berikut : 


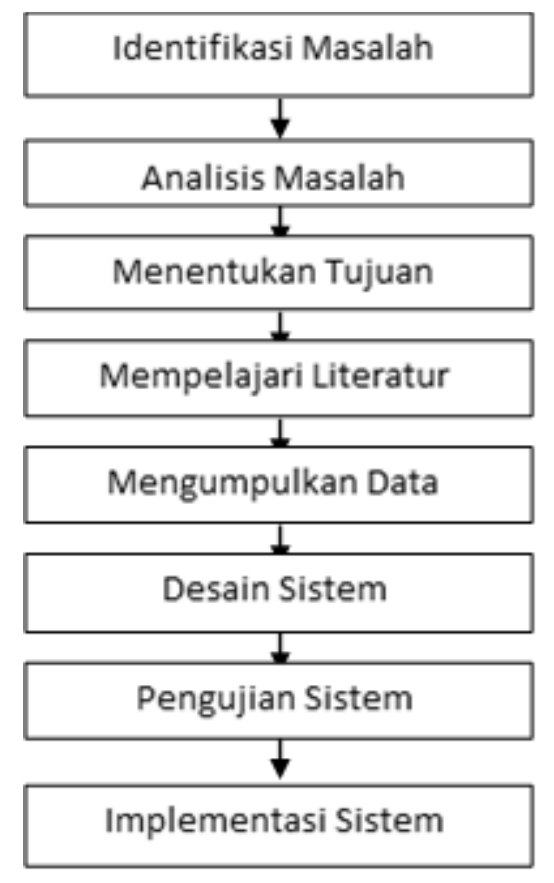

Gambar : Kerangka Kerja Penelitian

\section{Pembahasan}

Langkah-langkah yang dapat dilakukan dalam merancang Sitem pakar pendiagnosaan penyakit ternak adalah sebagai berikut:

a) Mengidentifikasi User Requirement

b) Sinkronisasi Database hewan ternak Dengan Database Sistem Pakar

c) Scripting/Pemrograman

\section{Pemodelan}

Dengan menggunakan model UML membantu dalam memvisualisasi, menspesifikasikan, membangun, dan pendokumentasian dari sebuah sistem pengembangan software berbasis $\mathrm{OO}$ (Object-Oriented). UML sendiri juga memberikan standar penulisan sebuah system blue print, yang meliputi konsep bisnis proses, penulisan kelas-kelas dalam bahasa program yang spesifik, skema database, dan komponen yang diperlukan dalam sistem pakar ini.

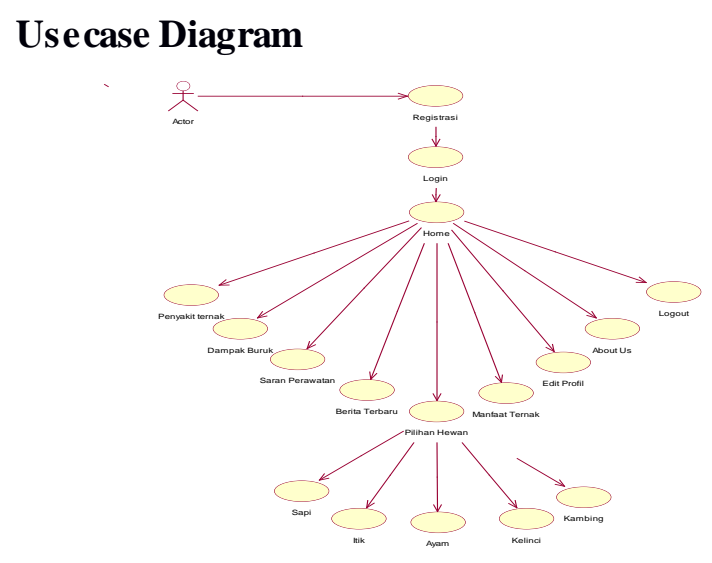

\section{Class Diagram}

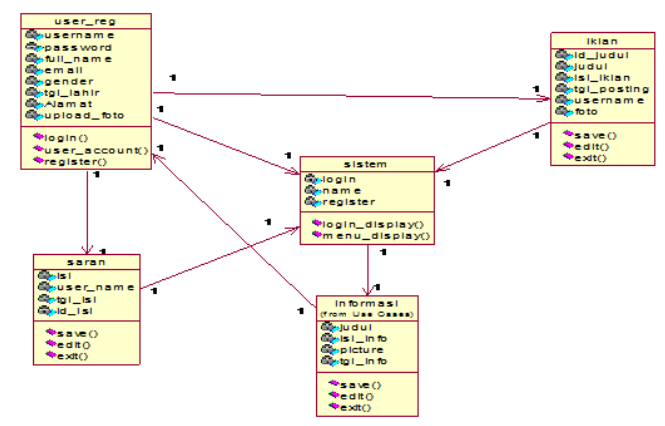

\section{Statechart Diagram}

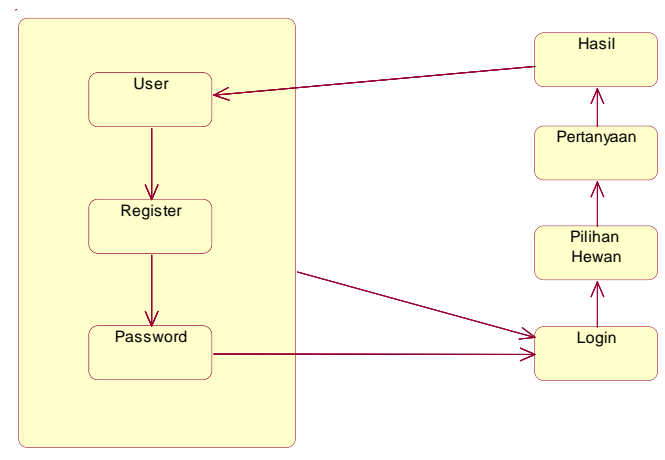

\section{Collaboration Diagram}

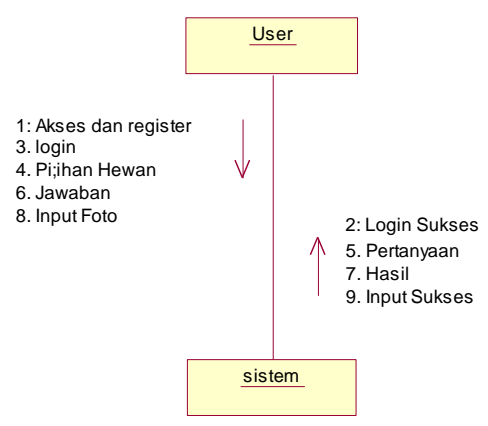




\section{Sequence Diagram}

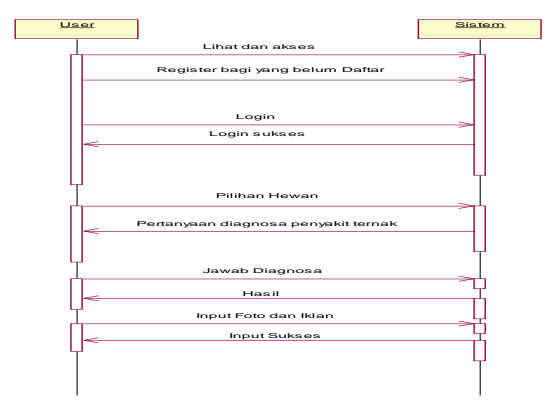

Activity Diagram

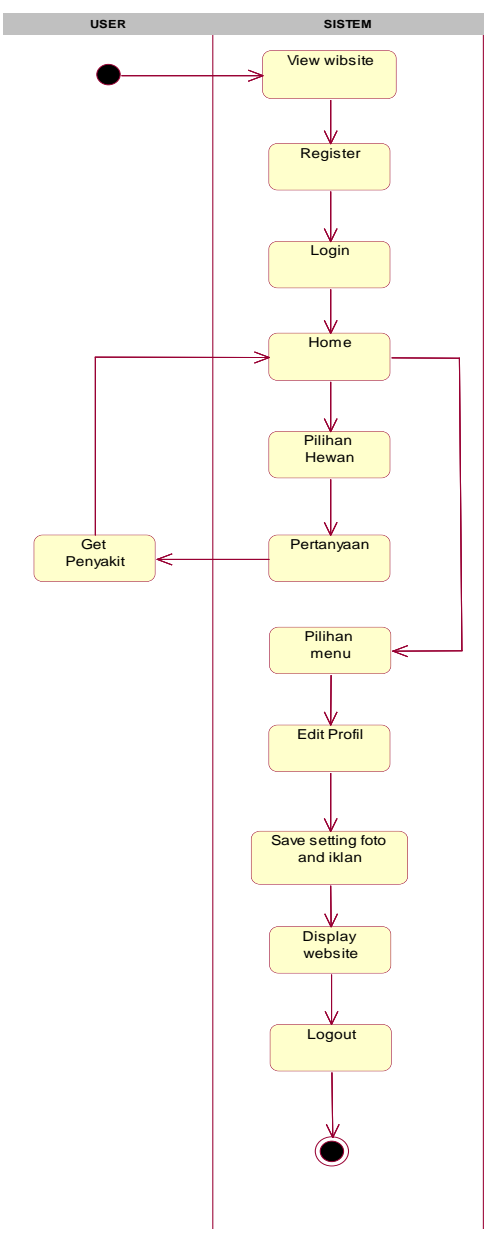

\section{SIMPULAN}

1. Perancangan system ini bertujuan untuk memberikan kemudahan kepada user unutuk dapat mengetahui tentang klasifikasi penyakit ternak dan bahaya apa yang di timbulkan dari penyakit ternak tersebut.

2. Basis web yang di gunakan dalam peneraparan system ini bertujuan agar user selaku pengguna yang membutuhkan banyak pengetahuan tentang penyakit ternak dapat secara leluasa pempergunakan nya tanpa di persulit sedikit pun

3. Pada jaman perkembangan Media informasi elektronik khusus nya internet yang semakin berkembang yang hampir di ketahui dan di pahami oleh sebagian besar masyarakat akan mempermudah untuk sebagi media penyampaian yang sangat baik karena pada umum nya masyarakat telah mengetahui bahwa internet merupakan pencarian informasi yang terbesar sehingga perancangan aplikasi ini berbasis Web sangat tepat

4. Tampilan sistem yang dirancang ini merupakan tampilan yang menarik dan mudah di pahami pemakaiannya sehingga pengguna dapat melakukan pengaksesan dengan mudah dan tidak merasa bingung untuk menggunakannya.

\section{UCAPAN TERIMAKASIH}

Terima Kasih kami ucapkan kepada seluruh pihak yang mendukung penelitian ini, baik secara materi maupun secara moril sehingga peneilitian ini dapat berjalan dengan semestinya.

\section{DAFTAR PUSTAKA}

[1] Flowler, martin, 2004, uml distilled 3th Ed, A Brief Guide to The Standart Object Modeling Language.

Yogyakarta : Andi

[2] Hakim,Lukmanul,2008, Membongkar Trik Rahasia

Para Master Php. Yogyakarta : Toko Media

[3] Kusrini, 2008, Aplikasi Sistem Pakar. Yogyakarta : Andi

[4] Muchtar, Abdullah Braniah, 2009, Mewaspadai Penyakit Berbahaya Pada Hewan dan Ternak.

Jakarta : Penebar Swadaya

[5] Puji, Diar Oktavian, 2002, Menjadi Programmer Jempolan Menggunakan Php. Yogyakarta : Mediakom 